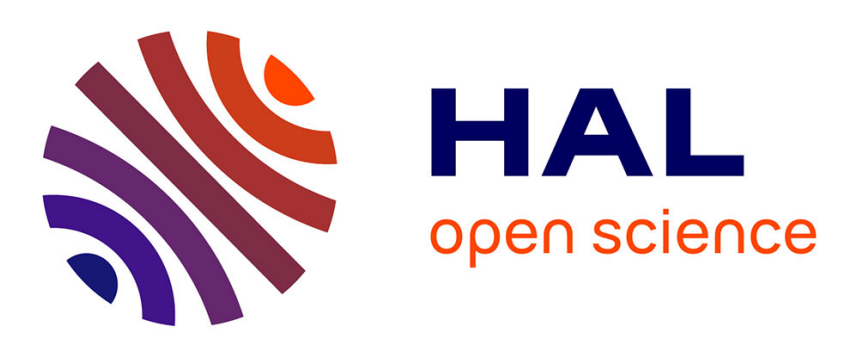

\title{
Oedometric compression and swelling behaviour of the Callovo-Oxfordia, argillite
}

\author{
Mehrdokht Mohajerani, Pierre Delage, Mohammad Monfared, Anh Minh
}

A.M. Tang, Jean Sulem, Behrouz Gatmiri

\section{To cite this version:}

Mehrdokht Mohajerani, Pierre Delage, Mohammad Monfared, Anh Minh A.M. Tang, Jean Sulem, et al.. Oedometric compression and swelling behaviour of the Callovo-Oxfordia, argillite. International Journal of Rock Mechanics and Mining Sciences, 2011, 48 (4), pp.606-615. 10.1016/j.ijrmms.2011.02.016 . hal-00636861

\section{HAL Id: hal-00636861 https://hal.science/hal-00636861}

Submitted on 28 Oct 2011

HAL is a multi-disciplinary open access archive for the deposit and dissemination of scientific research documents, whether they are published or not. The documents may come from teaching and research institutions in France or abroad, or from public or private research centers.
L'archive ouverte pluridisciplinaire HAL, est destinée au dépôt et à la diffusion de documents scientifiques de niveau recherche, publiés ou non, émanant des établissements d'enseignement et de recherche français ou étrangers, des laboratoires publics ou privés. 


\title{
Oedometric compression and swelling behaviour of the Callovo-Oxfordian argillite
}

\author{
M. Mohajerani *a, P. Delage ${ }^{\text {a }}$, M. Monfared ${ }^{\text {a }}$, A. M. Tang ${ }^{\text {a }}$, J. Sulem ${ }^{\text {a }}$, B. Gatmiri ${ }^{\text {b }}$ \\ International Journal of Rock Mechanics \& Mining Sciences, 48 (2011), pp. 606-615 \\ ${ }^{\text {a }}$ Ecole des Ponts ParisTech, UR Navier/CERMES, 6-8 av. B.Pascal, F77455 MarnelaVallée \\ cdx2, France \\ ${ }^{\mathrm{b}}$ ANDRA, Ch^atenay-Malabry, France
}

\begin{abstract}
The Callovo-Oxfordian (COx) argillite is a possible host rock for radioactive waste disposal in which the ANDRA underground laboratory of Bure (East of France) has been excavated. In this paper some aspects of the volume change behaviour of the COx argillite are investigated. To do so, high pressure oedometers with a maximum capacity of $113 \mathrm{MPa}$ have been used. In a first stage, swelling tests were carried out on samples initially compressed at constant initial water content (unsaturated) that were afterwards soaked under vertical loads, respectively, smaller and higher than the in-situ vertical stress. All samples exhibited swelling, even at stress higher than the in-situ one. In a second stage, standard step loading compression tests were carried out on samples previously saturated under the in-situ vertical load, so as to investigate the volume change behaviour under load cycles. The strain-stress curves obtained appear to be different to what is currently observed in overconsolidated or cemented clays with no clear appearance of yield and pre-yield reversible behaviour. The volumetric behaviour during both compaction and swelling is interpreted in terms of damage created by the collapse of pores within a fragile matrix. The amount of swelling observed is related to the extent of damage.
\end{abstract}

Keywords: Argillite, saturation, high pressure oedometer compression, swelling behaviour.

Please cite this paper as Mohajerani et al. (2011), Oedometric compression and swelling behaviour of the Callovo-Oxfordian argillite, International Journal of Rock Mechanics \& Mining Sciences, 48 (2011), 606-615.

*Corresponding author: Mehrdokht Mohajerani, UR Navier/CERMES, Ecole des Ponts

ParisTech, 6-8 av. B.Pascal, F77455 Marne la Vallée cdx2, France 


\section{Introduction}

The ANDRA underground research laboratory of Meuse-Haute-Marne, located near the village of Bure in the North-east of France [1,2], is composed of galleries excavated at the depths of $445 \mathrm{~m}$ and $490 \mathrm{~m}$ in a $200 \mathrm{~m}$ thick subhorizontal $\left(1^{\circ}-1.5^{\circ}\right.$ tilting) layer of the Callovo-Oxfordian (COx) argillite, an indurated clay rock dated 155 million years (limit upper-middle Jurassic). This layer is located in between two several hundred meters thick layers of Dogger (bottom) and Oxfordian (top) limestones. The main characteristics of the COx argillite are a very low hydraulic conductivity that restricts water transfer and a low diffusion coefficient that significantly delays solute transport. The COx argillite also has a low compressibility and its high sorption capacity for radionuclide makes it a proper potential site to store high activity radioactive wastes at great depth [3-5]. The in-situ stress state of the COx argillite formation has been investigated in detail in [1]. At the depth of $490 \mathrm{~m}$ where the cores tested in this paper were taken from, the following total stress values have been obtained: $\sigma_{v}=12.7 \mathrm{MPa}, \sigma_{h}=12.4 \mathrm{MPa}$ and $\sigma_{H}=12.7-14.8 \mathrm{MPa}$, indicating a nearly isotropic stress state.

Excavation of an underground repository induces shear and tensile cracks and creates an excavation damage zone (EDZ) around the galleries. The hydraulic conductivity of these cracks may be significantly higher than that of the undeformed host rock and this can affect the safety performance of the system. However, a gradual reconsolidation and sealing of the EDZ is expected after backfilling and repository closure, due to the creep and swelling capacity of the COx argillite. Hence, in the long-term view, the self-sealing capacity of clay rocks during the resaturation phase of the EDZ makes them particularly suitable for waste confinement.

Indeed, interesting self sealing behaviour of cracks, apparently due to the expansion of the hydrated clay fraction mobilised in the cracks $[6,7]$ has been experimentally evidenced. As a consequence, it appeared interesting to investigate the effect of damage on the swelling behaviour of argillite. In this context, a recent example of tunnelling in swelling ground has been reported by Carter et al. [8]. From field observations and laboratory tests, they [8] observed that swelling was highly enhanced in sheared zones and showed that either natural mechanical disturbance (fault, shear band) or man induced disturbance (excavating-trimming) could break down the bonds that in normal rock mass confine the swelling clays from freely expanding, thus promoting swelling. Aversa et al. [9], in their study on the mechanical behaviour of Italian tectonised shales, performed oedometric tests and observed that samples compressed under higher stresses had a greater swelling index, a feature that they related to the presence of discontinuities.

Oedometers were also used to determine the poroelastic parameters of the COx argillite. Vincké et al. [10] performed a series of tests including loading-unloading cycles in axial stress (with constant pore pressure) and loading-unloading cycles in pore pressure (under constant axial stress). They obtained values for the Biot coefficient $(b)$ ranging from 0.4 to 0.8 with vertical stress between 9 and $35 \mathrm{MPa}$. Bemer et al. [11] found values ranging from 0.45 to 0.65 and an oedometric modulus ranging from 1 to $5 \mathrm{GPa}$ under values of Terzaghi's effective axial stress between 5 and 25MPa. Homand et al. [12] obtained values of $b$ between 0.55 and 0.99 with an axial stress between 8 and $24 \mathrm{MPa}$, and a drained oedometric modulus between 1.4 to $6 \mathrm{GPa}$ with an axial stress between 2 and $24 \mathrm{MPa}$. All these parameters have been measured under axial stresses below 25MPa, a value lower than the uniaxial compressive strength of the COx argillite $(25-30 \mathrm{MPa})[5,13]$. This rather wide range of measured poromechanic parameters is likely to be due to various factors including the natural variability of the deposit (there are some significant changes in clay and carbonate contents with depth), the effects of anisotropy, the different initial state of the tested samples with 
respect to damage (due to extraction, stress release, drying, storage, transport and specimen trimming), to the initial water content and saturation degrees and to the saturation method applied prior to testing (when performed).

In this paper, the compressive/swelling behaviour of the COx argillite in relation with the effects of damage was investigated by means of oedometric tests. A first series of tests was carried out by soaking specimens that were previously compressed, at their initial water content, under stresses conditions smaller, close or higher than the in-situ one. In well preserved samples, swelling should only appear under a stress lower than the in-situ one and any swelling under higher stress could indicate the existence of pre-induced cracks. A second series of high pressure compression tests was carried out on carefully saturated samples, providing information on the compressive/swelling behaviour along various loadingunloading paths. The 1D configuration of the test also allowed to estimate the sample permeability by using the analytical solution governing the pore fluid dissipation in samples submitted to a constant vertical stress.

\section{Material studied and samples preparation}

\subsection{Callovo-Oxfordian Argillite}

The Callovo-Oxfordian (COx) argillite is an indurated clay of low porosity, low permeability and with a relatively high strength. Its mineralogical composition varies with depth. At a $490 \mathrm{~m}$ it contains $45 \%$ clay with $30-35 \%$ illite, $0-5 \%$ kaolinite and chlorite and 60-65\% interstratified illitelsmectite. COx clay also contains $28 \%$ carbonate (calcite), $23 \%$ quartz and 5\% feldspars, pyrite, iron oxides [14]. The smectite percentage in the clay fraction is responsible for the observed swelling capacity. The total porosity measured by Esteban [15] lies between $13 \%$ at levels that contain the highest carbonate fraction and $19.5 \%$ at levels having the highest clay content. Robinet [16] mentions that porosities as high as $27.5 \%$ can be found in layers containing a significant quantity of pyrite. The porosity of the samples tested here that come from the lower layers of the COx argillite deposit was generally found around $22 \%$ (Table 1).

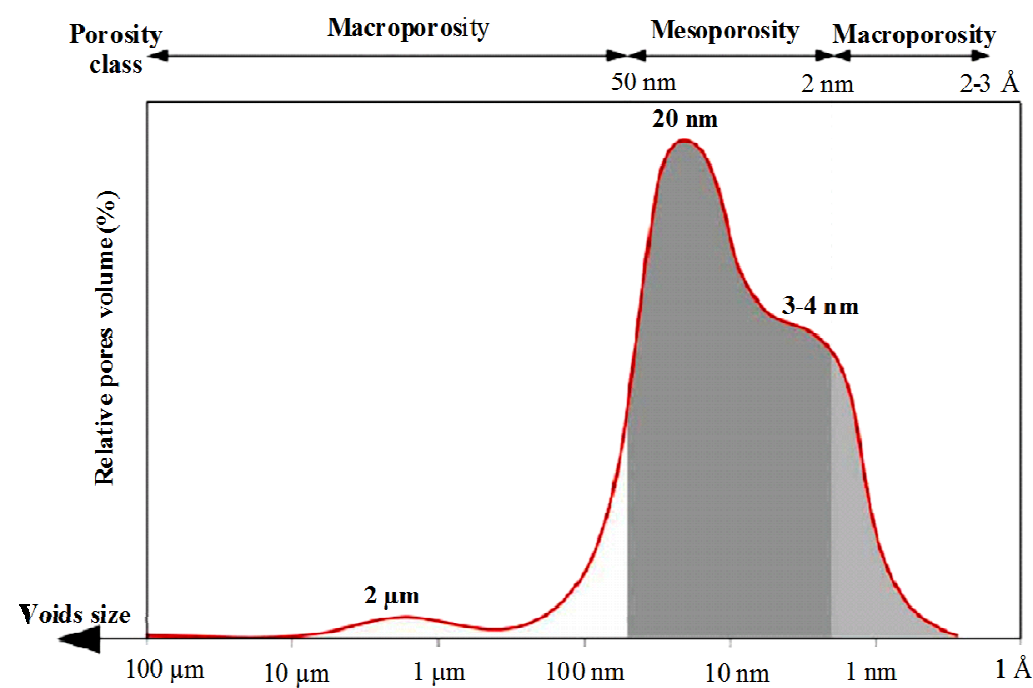

Figure 1: Pore size distribution of the COx argillite (mercury intrusion), after [17].

The clay minerals have a lamellar structure with crystals composed of 10-100 stacked elementary layers of different silicates. Figure 1 presents the pore size distribution curve obtained by using mercury intrusion porosimetry [17] that shows a well represented pore 
population at $20 \mathrm{~nm}$ with a second one at around 3-4 nm. The $20 \mathrm{~nm}$ pore population is related to the average entrance porosity within the clay fraction [17]. As quoted by Montes et al. [18], the hydration and/or dehydration of the swelling clay minerals could generate changes in the clay structure of the rock, with a dependency of the water sensitivity on the pore structure, on the particle size and on the total porosity. By using digital image correlation (DIC), Bornert et al. [19] recently provided interesting results showing, within the same specimen, significant changes in local stiffness according to the clay percentage of the zone considered.

\begin{tabular}{|c|c|c|c|c|c|}
\hline Sample & EST27396 $n^{\circ} 1$ & EST27396 $n^{\circ} 2$ & EST27396 n 3 & EST28522 $n^{\circ} 1$ & EST28522 $n^{\circ} 2$ \\
\hline Depth (m) & \multicolumn{3}{|c|}{483} & \multicolumn{2}{|c|}{481} \\
\hline Water content $(\%)$ & 5.9 & 6.6 & 6.3 & 7.1 & 6.1 \\
\hline Degree of saturation (\%) & 54.2 & 60.6 & 57.8 & 68 & 56 \\
\hline Porosity(\%) & 22 & 22 & 22 & 22 & 22 \\
\hline $\begin{array}{l}\text { Measured relative humidity } \\
(\%)\end{array}$ & 78 & 81 & 80 & 87 & 79 \\
\hline Suction (MPa) & 34 & 28 & 30 & 17 & 32 \\
\hline Sample diameter $(\mathrm{mm})$ & \multicolumn{3}{|c|}{50} & \multicolumn{2}{|c|}{38} \\
\hline Sample height (mm) & \multicolumn{3}{|c|}{15} & \multicolumn{2}{|c|}{10} \\
\hline Type of test & \multicolumn{3}{|c|}{$\begin{array}{l}\text { Compression followed by swelling under various } \\
\text { constant stresses }(8,10 \text { and } 12 \mathrm{MPa})\end{array}$} & \multicolumn{2}{|c|}{$\begin{array}{l}\text { High pressure compression with } \\
\text { loading cycles }\end{array}$} \\
\hline
\end{tabular}

Table 1. Initial characteristics of the tested samples.

\subsection{Sample preparation and setting}

The process of saturation of argillite samples prior to testing is of utmost importance given the sensitivity of argillite to changes in water content. Indeed, the results of Pham et al. [13] showed that decrease in water content (obtained by submitting samples to different values of controlled relative humidity $\mathrm{RH}$ ) leads to significantly increase the unconfined compressive stress of COx samples (from $27 \mathrm{MPa}$ at $98 \% \mathrm{RH}$ to $57 \mathrm{MPa}$ at $32 \% \mathrm{RH}$ ). The saturation of low permeability argillite samples (with hydraulic conductivity $k$ around $10^{-20}$ $10^{-21} \mathrm{~m}^{2}$ ) that have been desaturated during the processes of in-situ coring, sample storage, transport to the lab and finally sample trimming is difficult and can be significantly long. Also, saturation under zero stress condition can cause hydraulic damage evidenced by the appearance of cracks resulting from hydration and swelling, as shown by Valès [20] and Bornert et al. [19] by using Digital Image Correlation. The quality of the saturation prior to testing is indeed fundamental to investigate the poromechanical behaviour [11] with respect to microstructure effects and induced cracks [18]. The saturation method used by Bemer et al. [11] consisted in exposing the samples to an atmosphere close to $100 \% \mathrm{RH}$ by putting them into a dessiccator containing pore water put at chemical equilibrium with crushed $\mathrm{COx}$ argillite from the same initial plug. Resaturation occurred through the vapour phase until the sample weight stabilised, which required 1 or 2 months. A 3\% swelling was observed during this phase in which no stress was applied on the sample. In other tests [3?12] resaturation was performed close to in situ stress conditions under a $4 \mathrm{MPa}$ confining pressure and a $1 \mathrm{MPa}$ back pressure with a chemical composition of the pore water close to the one of the in situ pore water. Since swelling was observed under these conditions, these authors $[3,12]$ also 
carried out tests under a confining pressure of $8 \mathrm{MPa}$ and a back pressure of $1 \mathrm{MPa}$ to prevent swelling.

In this paper, particular care was taken to avoid any swelling prior to testing. To do so, the samples were placed in the oedometer cell with initially dry porous disks that were afterwards water saturated so as to infiltrate the sample while maintaining the vertical strain close to zero by appropriate manually controlled loading. The mineralogical composition of the water injected in clay samples is known to be of utmost importance with respect to the clay-water interactions and to swelling behaviour. Since the specimens to be tested have been somewhat desaturated due to the evaporation of pure water (with salts remaining within the sample), the only way to bring back their pore water to its initial natural chemical composition is to infiltrate pure water at constant volume. This is what has been done here. To conserve afterwards the correct salt concentration, swelling tests should be conducted by infiltrating water with the same salt concentration as that of the pore water. This has not been done here in a purpose of simplicity and pure water was also used in swelling tests (note however that the situation is improved when swelling tests are conducted after compression tests, since some of the natural pore water has been expelled in the porous disk). Compared to natural pore water, the absence of salt in the water used tends to enhance the swelling behaviour.

Two kinds of oedometer cells were used. The three tests EST27396 n¹, EST27396 n², EST27396 $\mathrm{n}^{\circ} 3$ were performed in oedometer rings of 50mm in diameter whereas the two tests EST28522 $\mathrm{n}^{\circ} 1$, EST28522 $\mathrm{n}^{\circ} 2$ were carried out in a $38 \mathrm{~mm}$ diameter rings. Samples were cored to the desired diameter by using a diamond barrel.

The cored specimen was afterwards inserted in the ring and its top and bottom faces were carefully polished by using a sand paper sheet placed on a small plane wooden board. The polishing of the upper and down faces of the sample was completed once the wood piece came in contact with the cylindrical section of the metallic ring, thus achieving exactly the required sample thickness with two flat, regular and parallel faces. The loading direction was taken perpendicular to the stratification of samples.

The initial degree of saturation was determined by carefully measuring the sample volume (by using a precision calliper). The water content was determined by measuring the initial and final weights of a rock piece before and after drying in the oven at $105^{\circ} \mathrm{C}$ for one day. The initial suction of the samples was determined by using a chilled mirror dew-point hygrometer [21] fabricated by General Eastern. This device is based on the precise measurement of the relative humidity of the sample. It provides the total suction value within a period of time of about 15 min according to Kelvin's law [22, 23]:

$s=u_{a}-u_{w}=\frac{-R T}{g M} \ln h$

where $u_{a}$ and $u_{w}$ are respectively the air and water pressure, $s$ is the total suction, $R$ is the universal (molar) gas constant $\left(R=8.3143 \mathrm{~J} . \mathrm{mol}^{-1} . \mathrm{K}^{-1}\right), T$ is the absolute temperature $(\mathrm{K}), g$ is the gravity acceleration $\left(g=9.81 \mathrm{~m} . \mathrm{s}^{-2}\right), M$ is the water molecular mass $\left(M=18.016 \mathrm{~g} . \mathrm{mol}^{-1}\right)$ and $h$ is the relative humidity. At $20^{\circ} \mathrm{C}, \frac{-R T}{g M}=137.837 \mathrm{MPa}$

As any technique based on vapour exchanges, the dew point hygrometer is suitable at high suctions, preferably higher than $3 \mathrm{MPa}[22,24]$. In this device, the sample is placed in a sealed chamber containing a mirror that can be chilled with a very precise temperature control. Once the relative humidity of the air in the chamber is equilibrated with that of the sample, the mirror is chilled down to the dew point temperature corresponding to the relative humidity in the chamber (the drier the atmosphere, the lower the dew point temperature). The accurate determination of the dew point is made by detecting the condensation of micro water bubbles 
on the surface of the mirror by an optical system. The suction is deduced from the relative humidity that corresponds to the dew point temperature.

The parameters characterising the initial states of the samples are presented in Table 1. As expected, with initial suctions as high as 17 to $34 \mathrm{MPa}$, the samples were significantly desaturated just after trimming. According to calculations by using Jurin's law [25] based on the pore size distribution curve presented in Figure 1 [17] and adopting the hypothesis of cylindrical pores, one can estimate the air entry value of the COx argillite. Jurin's law [25] is written as follows:

$u_{a}-u_{w}=\frac{4 \sigma_{s} \cos \theta}{D}$

in which $\sigma_{s}$ is the surface tension at the air-water interface and $\theta$ is the contact fluid-solid angle (for water, $\cos \theta=1$ and $\sigma_{s}=72.75 \times 10^{-3} \mathrm{~N} / \mathrm{m}$ at $20^{\circ} \mathrm{C}$ ). $D$ is the diameter of the cylinder. With $D=20 \mathrm{~nm}$ (see Figure 1), the air-entry value of the COx sample can be estimated around $14 \mathrm{MPa}$, indicating probable air continuity within the argillite at higher suction.

In this study, a high pressure oedometer developed in CERMES was used [26]. The apparatus has a double lever arm (with one lever arm multiplying the load by 5 and the second one by 10) able to apply a maximum axial stress of $113 \mathrm{MPa}$ on a $38 \mathrm{~mm}$ diameter specimen. The specimen is placed on a metallic porous disk inserted in the cell base and connected to two lateral valves that allow satisfactory saturation of the porous disk as described later in more details. Another metallic porous disk is placed on top of the sample to allow vertical drainage through the top and bottom faces. Vertical displacements are monitored by using an electronic LVDT transducer connected to a data acquisition system.

An initial calibration of the system was carried out by running a test with no sample in the ring so as to account for the effects of the compression of the top and bottom metallic porous disks, of the cell and of the piston. A reversible response of the system was observed after applying various loading cycles between 0 and $113 \mathrm{MPa}$. During all tests, the compression displacement of the sample was obtained by subtracting the calibrated elastic compression of the system from the total measured compression displacement.

\section{Swelling tests}

One of the standard techniques used to estimate the swelling stress of soils consists in running in parallel several oedometric tests in which the samples (at given initial water content) are first loaded under various vertical stresses that are chosen smaller and larger than the estimated swelling stress. The samples are then soaked under these stresses while measuring the volume changes. The swelling stress is interpolated by drawing a curve passing through all the experimental points (either after swelling or compaction) at the intersection of the curve with the no volume change line.

This approach has been applied to the COx argillite. Knowing the in-situ condition (approximated by a total vertical stress $\sigma_{v}=12 \mathrm{MPa}$ and a pore pressure $u=4 \mathrm{MPa}$, [1]), three samples were loaded (at given initial water content, see Table 1) to vertical stresses equal to 8 , 10 and $12 \mathrm{MPa}$ under which they were subsequently soaked.

Based on the values of the Biot coefficient presented in the Introduction (between 0.4 and 1 ), the estimated effective stress could be between 8 and 10.4MPa. Hence, the first load $(8 \mathrm{MPa})$ corresponds to the lower bound of the in-situ vertical effective stress, the second value $(10 \mathrm{MPa})$ to the upper bound whereas the third one $(12 \mathrm{MPa})$ is larger. In such 
conditions, one should theoretically observe some swelling under $8 \mathrm{MPa}$, little volume change under $10 \mathrm{MPa}$ and some compression under $12 \mathrm{MPa}$.

The initial characteristics of the three samples are presented in Table 1. As expected, the water saturation is far from being complete in the samples. The initial compression was conducted at constant initial water content around 6\% (see exact values in Table 1) by following a standard step loading procedure with the load doubled at each step.

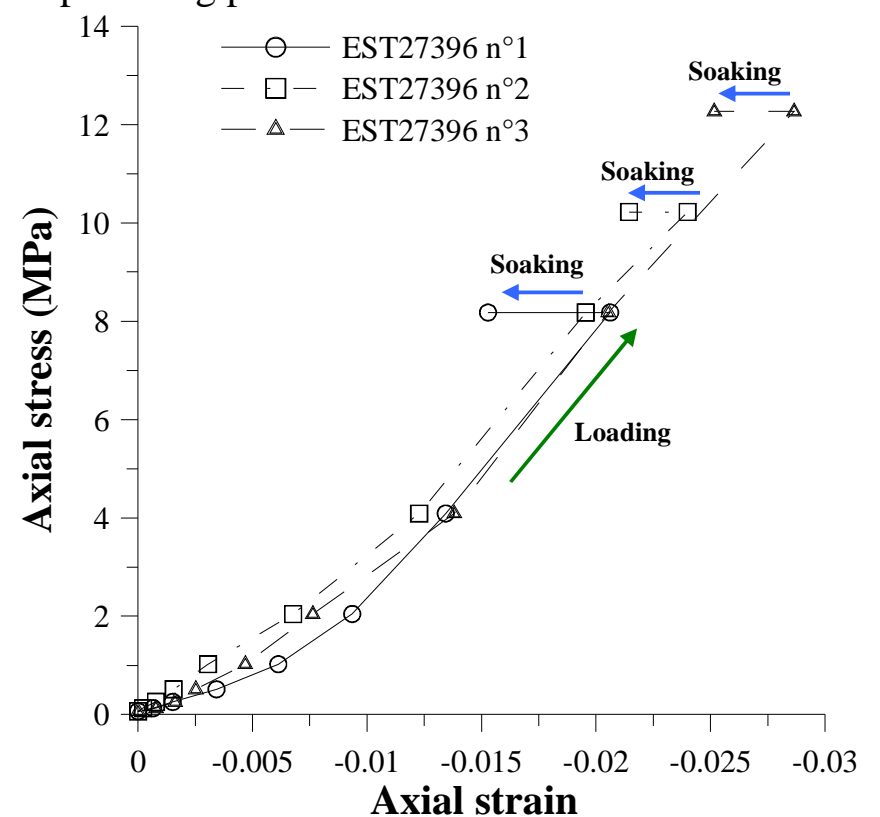

Figure 2: Oedometric compression curves and hydration test under various vertical loads (EST27396 $n^{\circ} 1,2$ and 3).

Results are presented in Figure 2 in an axial stress versus vertical strain diagram. One can observe that the three compression curves are reasonably similar, probably due to comparable initial unsaturated states (Table 1). Once soaked, swelling is observed under the three stresses applied, including under the higher one (12MPa) that is larger than the in-situ vertical effective stress. The swelling strains are equal to $0.53,0.26$ and $0.35 \%$ under 8,10 and $12 \mathrm{MPa}$ respectively. They are not ordered with respect to the stress applied as expected, since a higher strain is observed under $12 \mathrm{MPa}$ compared to $10 \mathrm{MPa}$.

It is well known that a sample should not swell under a vertical effective stress higher than the in-situ effective stress in the case of 'perfect sampling' [27]. However, the quality of the COx samples has been affected by the excavation, stress release, drying, transport and trimming procedures and all samples hence contain some induced cracks that result in an enhanced swelling behaviour.

During the loading phase, some crack closure can occur under low stress level but at higher stress, new cracks can form and propagate. It is thus expected that after loading the swelling properties during hydration would be enhanced.

\section{High pressure oedometric compression tests}

Two oedometric compression tests were carried out on two samples EST28522 $\mathrm{n}^{\circ} 1$ and EST28522 $\mathrm{n}^{\circ} 2$ (see Table 1). The sample was placed into the oedometer ring that was previously coated with grease to reduce friction along the lateral surface of the specimen. The porous disks were kept dry so as to ensure a well controlled saturation procedure under in-situ stress conditions close to the natural ones. To ensure good contact between the sample, the porous disks and the piston, a previous low stress loading-unloading cycle was applied prior 
to injecting pore water up to $1 \mathrm{MPa}$ (a value deemed small enough to preserve the sample from any change). During this cycle, all pore water valves were closed to avoid any drying of sample. For the same reason, this preliminary stress cycle was run rapidly, in less than 5 minutes.

The saturation of the bottom porous disk was carried out by infiltrating water under small pressure into the disk. To do so, one of the drainage valves of the cell base was connected to the pore water reservoir whereas the other one was kept open so as to allow the evacuation of the air from the dry porous disk during water infiltration. This valve was closed once water started to flow out.

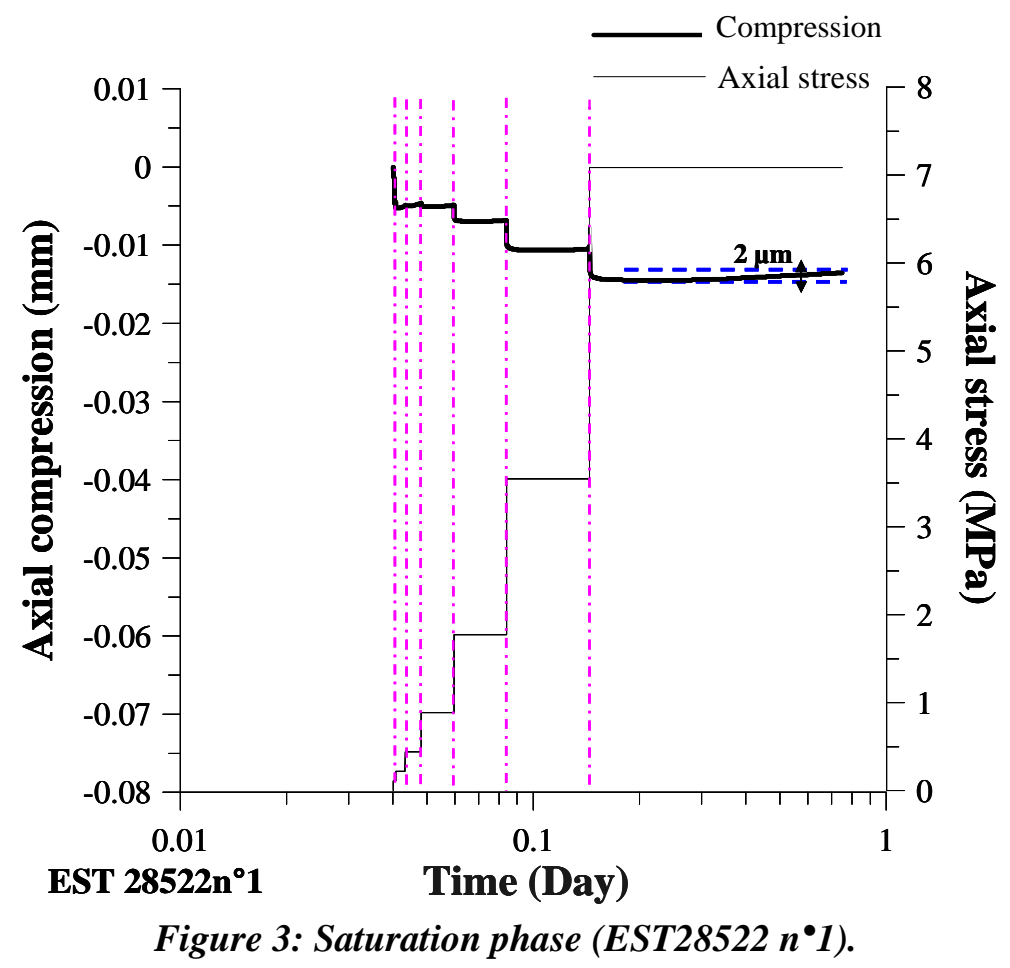

Two different saturation procedures with minimised swelling were followed prior to carry out the compression test. In test EST28522 $\mathrm{n}^{\circ} 1$, compression was carried out up to $7.09 \mathrm{MPa}$ at constant water content. Under this stress, water was infiltrated which resulted in a slight swelling as shown in Figure 3. Once a $2 \mu \mathrm{m}$ swelling was reached, the load was doubled and compression started with no more swelling. The saturation procedure was improved in test EST28522 $\mathrm{n}^{\circ} 2$ as follows. Water was infiltrated under a lower stress of $3.5 \mathrm{MPa}$ (a value lower than the interval proposed for the in situ effective stress between 8 and 10.4). As soon as the monitored vertical displacement reached a maximum value of $2 \mu \mathrm{m}$, the applied load was doubled. This procedure was carried out until reaching a load with no further swelling.

As shown in Figure 4 (sample EST28522 $\mathrm{n}^{\circ}$ ), swelling is observed up to $1.75 \mathrm{MPa}$ with compression starting at 3.5MPa. Further inspection of Figure 4 shows that the constant volume condition is in fact approximate. Whereas, swelling above the initial sample volume is indeed maintained below $2 \mu \mathrm{m}$ as planned. 


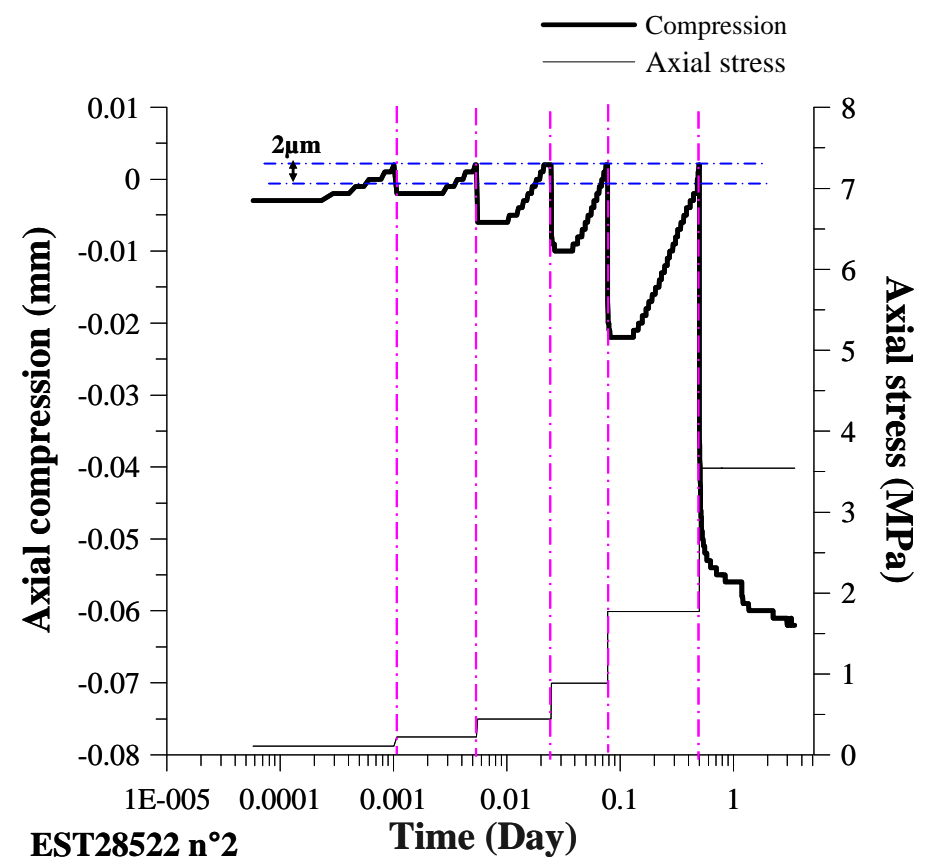

Figure 4: Saturation phase (EST28522 $\left.n^{\circ} 2\right)$.

\section{Test 1: Test EST28522 $n^{\circ} 1$ with one load cycle}

A loading-unloading cycle was carried out up to the maximum vertical stress of $113 \mathrm{MPa}$ on sample EST28522 $\mathrm{n}^{\circ} 1$. The cycle was conducted by steps with the load doubled at each step. The unloading sequence was performed in the same way. Each loading step lasted up to 2-3 days so as to reach vertical strain stabilization. Strain/time curves under constant load were monitored at each step. The total test duration test was about one month (The saturation procedure adopted is the same as that of Figure 3). The results of test EST28522 $\mathrm{n}^{\circ} 1$ are presented Figure 5 where the changes of the vertical strain and the load are plotted versus time. One can see that a vertical compression strain of $10 \%$ is attained under the maximum stress of $113 \mathrm{MPa}$. The behaviour during the unloading phase is also remarkable with a significant swelling observed at each step and a final strain bringing back the sample very close to the initial state.

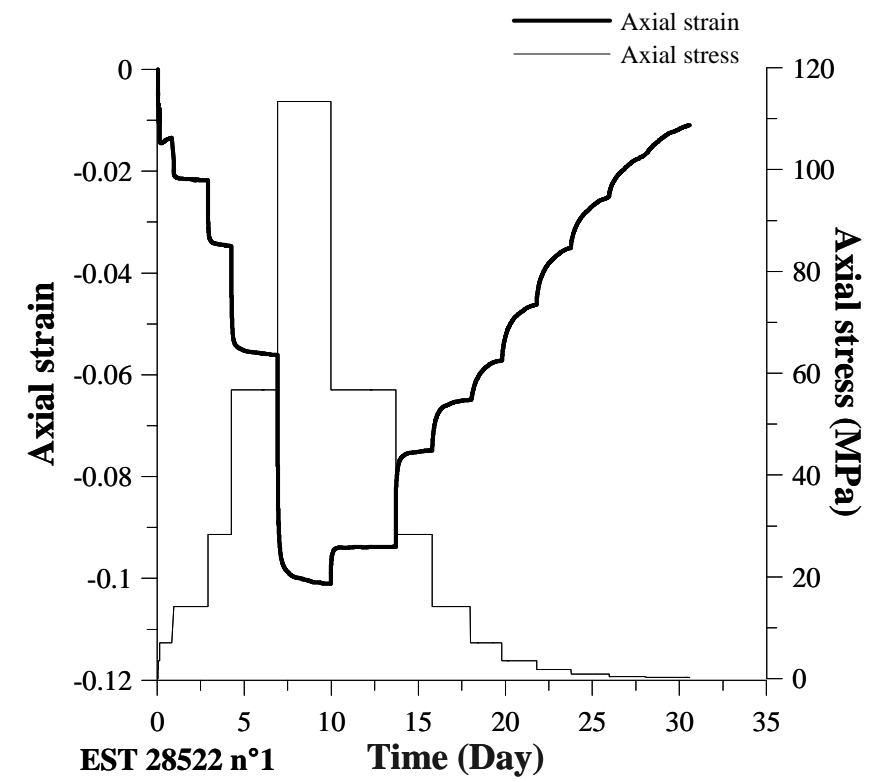

Figure 5: Axial compression and axial stress versus time (EST28522 $\left.n^{\circ} 1\right)$. 
This trend is also observed in Figure 6 in which the changes in vertical load versus vertical strain are plotted in linear scale. Under an applied axial stress as high as $113 \mathrm{MPa}$, the sample is very likely beyond the elastic limit. At maximum axial load the compressive strain is $9.6 \%$, a value comparable with that obtained by Heitz and Hicher [28] who obtained an 8\% strain under $100 \mathrm{MPa}$ in an oedometer test performed on a COx sample.

The unloading curve is strongly non linear and similar to that of swelling plastic soils with a significant swelling mobilised at the end of the unloading phase. Actually, the progressive mobilisation of swelling is observed in the diagram that clearly shows that the swelling brings back the sample volume very close to the initial volume, with more than $60 \%$ of the swelling mobilised between 10 and $0 \mathrm{MPa}$.

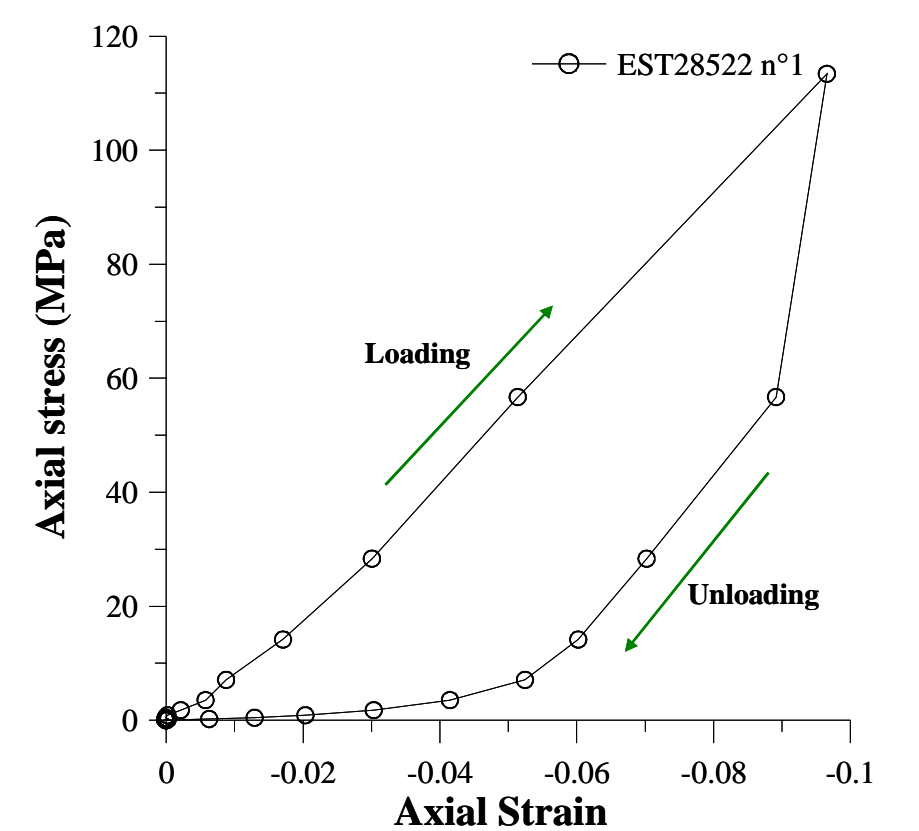

Figure 6: Oedometric compression curve (EST28522 $\left.n^{\circ} 1\right)$.

\section{Test 2: Test EST28522 $n^{\circ} 2$ with two loading cycles}

To confirm the results of the previous compression test and to further investigate the significant swelling observed upon unloading, a second oedometric test was carried out on sample (EST28522 $\mathrm{n}^{\circ} 2$ ) in which an intermediate loading cycle was performed before reaching the maximum load of $113 \mathrm{MPa}$ (the saturation procedure adopted is the same as that of Figure 4). 


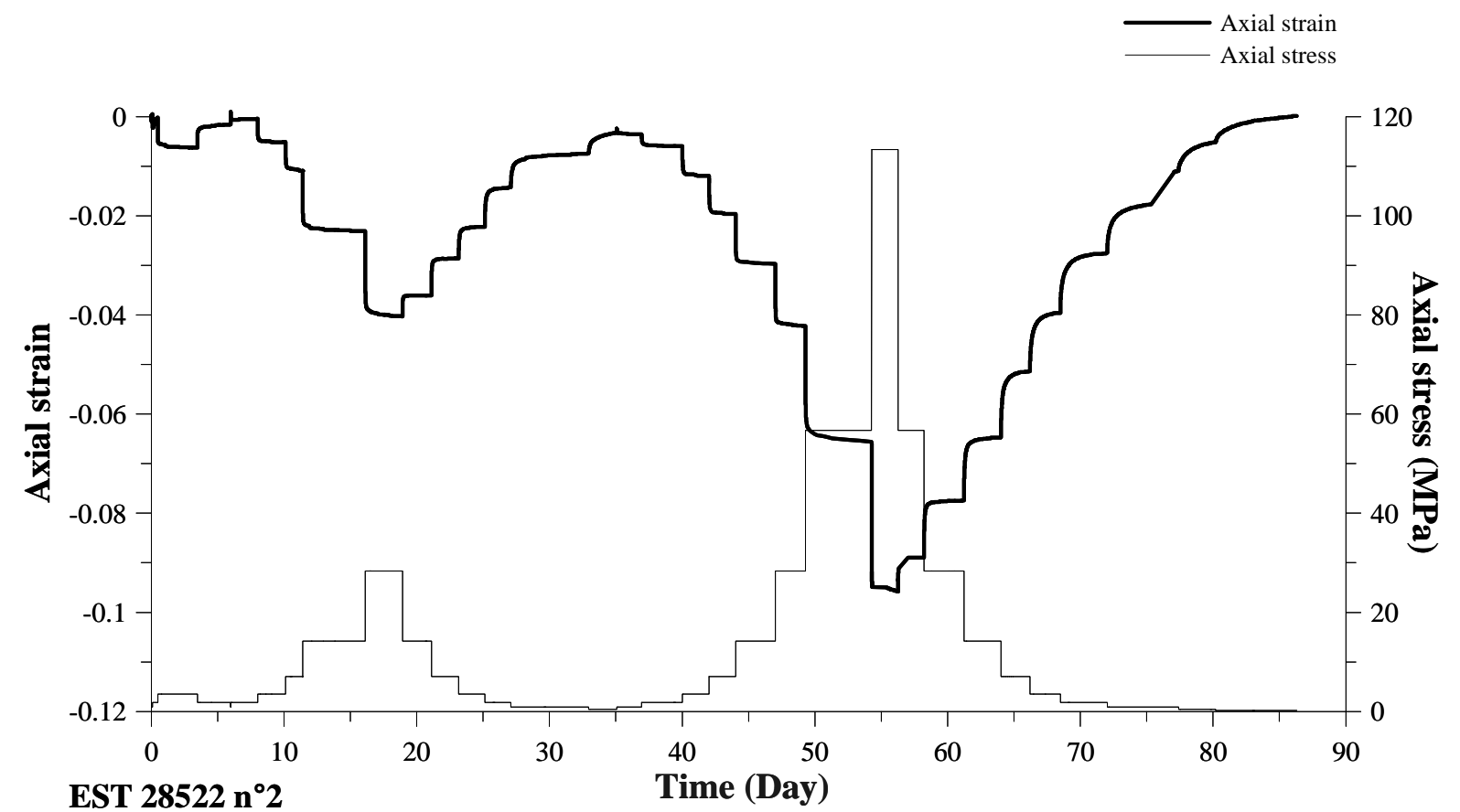

Figure 7: Compression strain and axial stress versus time (EST28522 $\left.n^{\circ} 1\right)$.

As seen in Figure 7, the sample was first loaded up to $28 \mathrm{MPa}$ and subsequently unloaded. It was preferred not to unload the sample below $0.4 \mathrm{MPa}$ so as to avoid reaching a void ratio larger than the initial one. The sample was subsequently re-loaded to $113 \mathrm{MPa}$ and unloaded down to zero. The test data are presented as a function of time in Figure 7 and the compression curve is presented in a diagram giving the axial stress versus the axial strain in Figure 8.

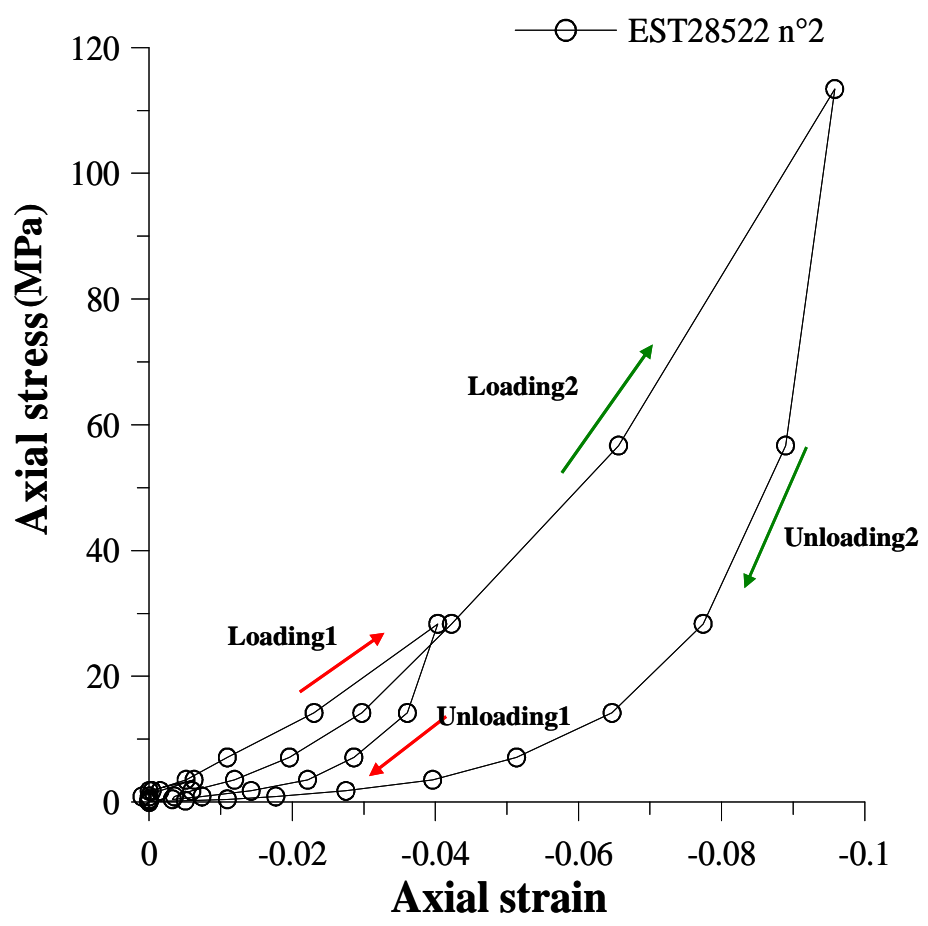

Figure 8: Compression curves (EST28522 $\left.n^{\circ} 2\right)$. 
At the end of the first cycle, the second loading curve between 0.4 and $28 \mathrm{MPa}$ passes below the first compression curve to join it at the maximum stress applied (28MPa). At higher stresses, the curve is in the prolongation of that of the first loading sequence.

The second unloading sequence is carried out from the maximum load of $113 \mathrm{MPa}$. The subsequent swelling under unloading is again significant and comparable to that observed in Figure 6 . The shape of the plot is similar to the previous one.

In order to compare the compression curves obtained here with the data already published by Aversa et al. [9] on Italian tectonised shales and by Heitz and Hicher [28] on various clay shales including the COx argillite, the strain-stress curves of tests 1 and 2 are now presented like these authors by plotting the changes in axial strain with respect to the decimal logarithm of the vertical stress (the standard presentation of oedometric curves in clays) in Figure 9. One can observe that the compression curves are reasonably similar.

Whereas the curved shape of the curve in the semi-log plot would allow the determination of a yield stress, as usually done in Soil mechanics, the linear plots of Figure 6 (test 1) and Figure 8 (test 2) did not show any evidence of yield behaviour. The curves have a slight curvature (much less than what is currently observed in clays) with no significant change of slope that could allow separate an elastic regime from a plastic one. It seems then difficult to define any yield stress for the COx argillite by using the standard interpretation of oedometric tests.

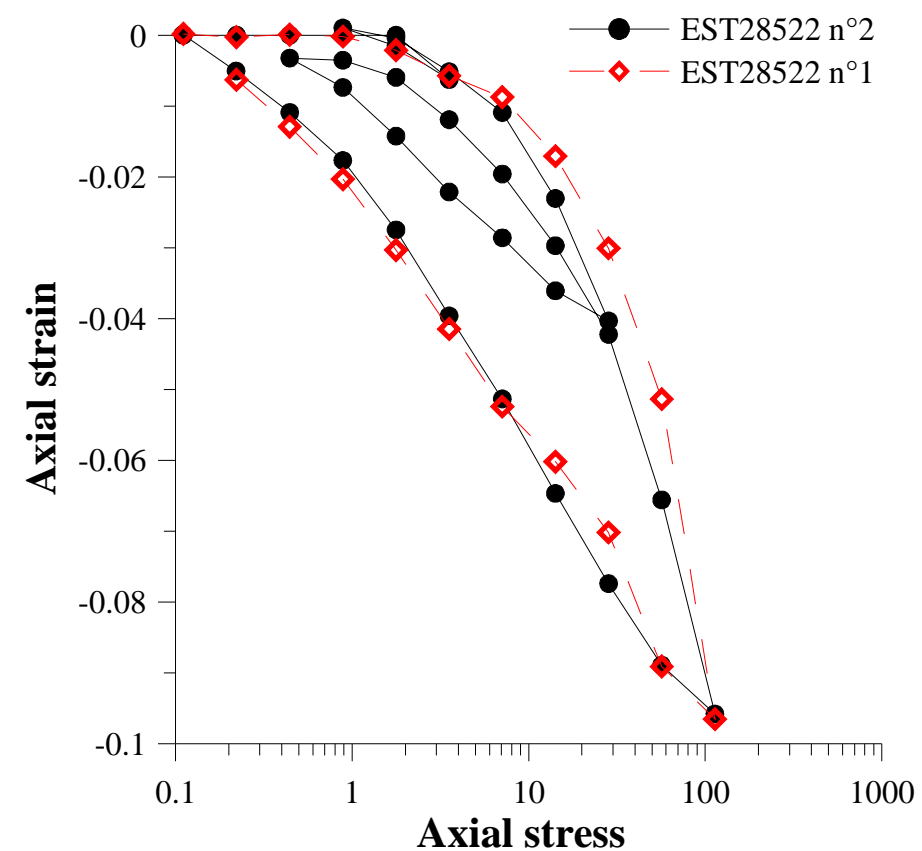

Figure 9: Oedometric strain-stress curves in semi-log plot (EST28522 $n^{\circ} 1$ and EST28522 $\left.n^{\circ} 2\right)$.

In Figure 9, one can observe that the average slope of the intermediate unloading curve is less than that of the final one, in accordance with the data obtained by Aversa et al. [9]. Accordingly, the swelling strain under the same stress decrement along the unloading path (between 28 and $14 \mathrm{MPa}$ for instance) is much higher in the sample compressed at $113 \mathrm{MPa}$ compared to that compressed at $28 \mathrm{MPa}$ (Figure 10).

This higher swelling potential at higher density is typical of swelling clays. This trend is illustrated in Figure 10 in which the swelling modulus (the slope of the swelling curve in an axial strain/axial stress diagram) is represented with respect to the axial stress. A clear distinction is observed between the first cycle at intermediate stress and the second one at maximum stress. 


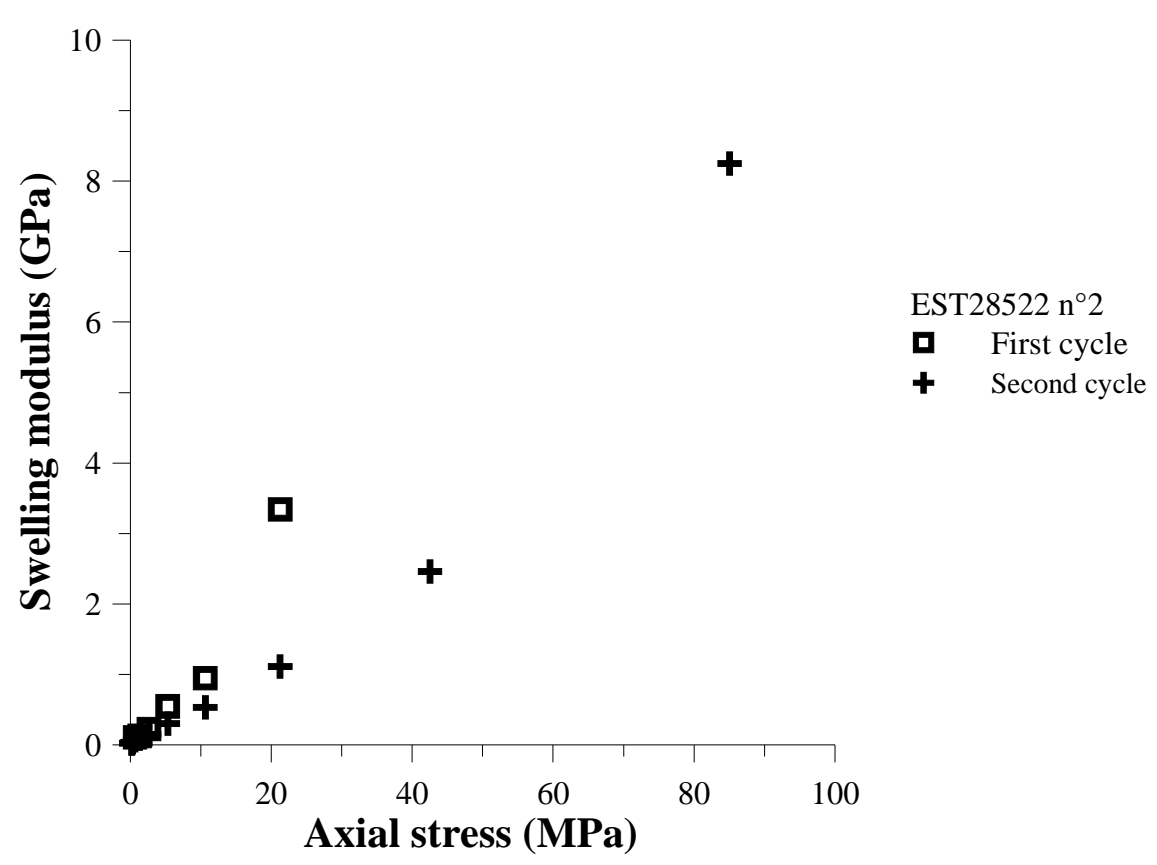

Figure 10: Variation of swelling modulus with axial stresses for two consecutive cycles (EST28522 $n^{\circ} 2$ )

\section{Discussion}

The main conclusion drawn from the oedometric tests carried out here is that the COx argillite exhibits significant swelling behaviour when hydrated along various hydromechanical paths. Some previous works (e.g. [6]) have linked this swelling capacity to the presence of cracks in the argillite, showing, in a sample with an artificial crack, that the swelling of the hydrated clay fraction (interstratified illite-smectite particles) was mobilised along the faces of the crack. The same phenomenon also explains the good sealing capacity of the argillite, made possible by the filling of the pore volume of the cracks by the swollen hydrated clay particles. In this regard, the swelling capacity can be related to the crack density, i.e. to the damage induced in the argillite. Conversely, significant swelling behaviour reflects significant damage.

Argillite is a fragile material and cracks can be created by various phenomena. Besides the cracks induced by shearing that result in a degradation of the elastic modulus as described in standard damage theory, the appearance of cracks has also been visually observed during drying and wetting phases (as an extreme case, a COx specimen placed in pure water progressively disaggregates due to the generation of a crack network along the bedding). Hydration cracks have also been locally observed by Valès [20] and Bornert et al. [19] by using digital image correlation (DIC) techniques. These observations confirmed the necessity of performing preliminary sample saturation under in-situ stresses to minimise any perturbations due to swelling, as observed in stiff swelling clays like Boom clay [29].

Swelling was observed in the first series of oedometric compression tests at constant water content (around 6\%) and initial degrees of saturation close to 60\% when wetting the specimens under a vertical stress higher than the in-situ one. This swelling is related to sample disturbance and drying induced damage during coring, extraction, storage, transport and sample trimming.

A further process of crack generation is suspected to occur during oedometric compression. Based on previous results obtained in sensitive soft clays [30-32] in which it appeared that compression occurred by the ordered collapse of pores, starting from the largest 
and progressively affecting smaller and smaller pores. This mechanism was confirmed by scanning electron microscope (SEM) observations that also showed that the elastic unloading rebound was due to the local swelling of the collapsed zones.

Although no SEM analysis has been performed in the COx argillite, it is proposed to also consider it as a fragile porous matrix that exhibits pore collapse during compression. Cracks are supposed to be formed due to local pore collapse, resulting in local disturbed zones with enhanced swelling capacity once hydrated. Since compression at higher stress induces the collapse of more pores, the swelling capacity of the compressed argillite is enhanced by the creation of additional cracks. For this reason, a sample compressed under a higher stress exhibits, under the same vertical load, a higher swelling potential (Figures 9 and 10).

The two oedometric compression curves obtained here are now compared to those of Bemer et al. [11] in Figure 11. The data of test EST28522 $\mathrm{n}^{\circ} 1$ with no loading cycle are quite comparable with one of the curves of Bemer et al. [11] whereas those of the test EST28522 $\mathrm{n}^{\circ} 2$ with an intermediate loading cycle exhibit a higher compressibility. Drained elastic oedometric moduli $\left(M_{\text {oedo }}\right)$ of the COx argillite are the slopes of stress-strain linear curve calculated from the unloading sequence close to the maximum applied stress, in an area where swelling appears to be impeded by the applied stress, with reasonably low swelling strain.

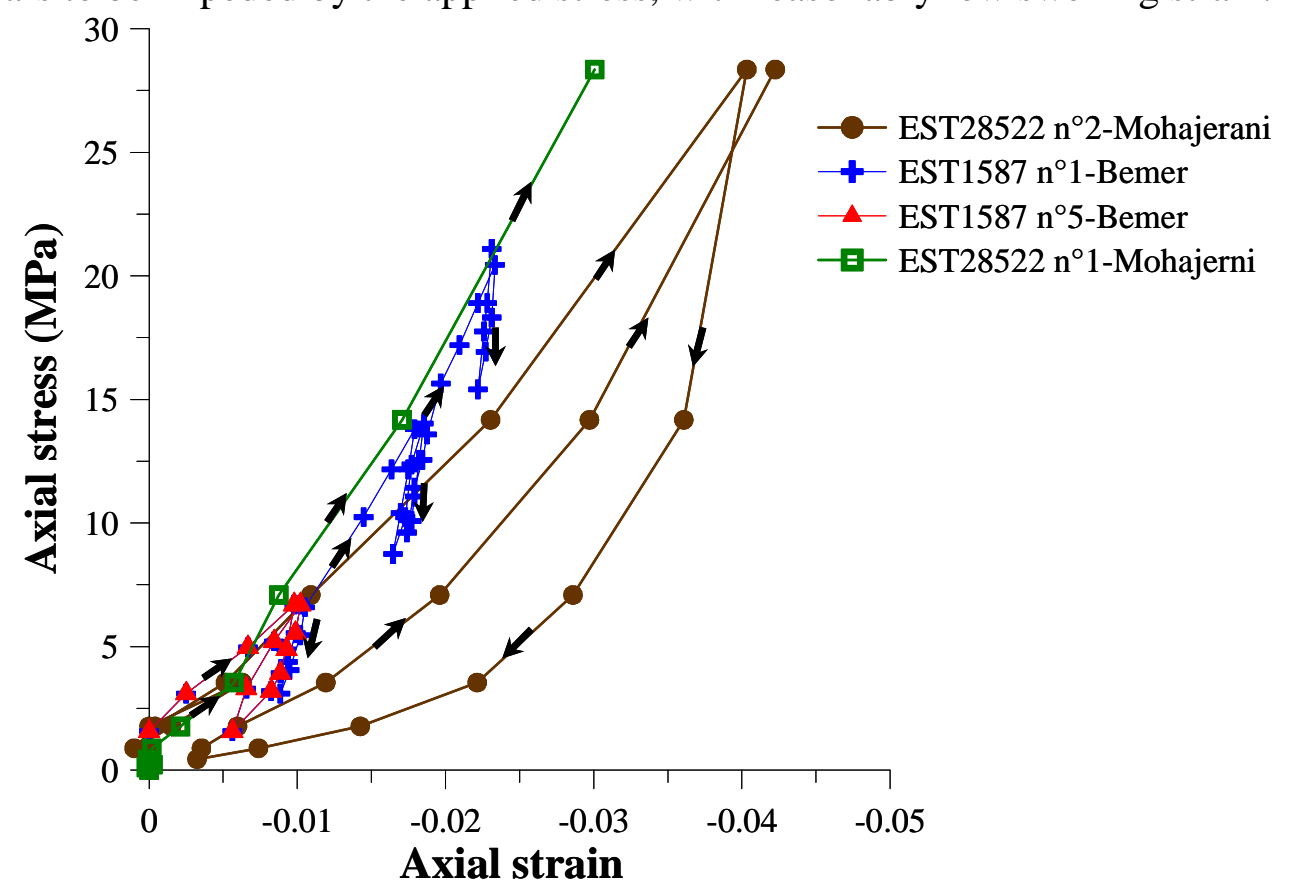

Figure 11: Comparison of the data obtained here with the oedometric compression tests of Bemer et al. [11].

In Figure 12, the calculated drained oedometric moduli $M_{\text {oedo }}$ are plotted and compared to that obtained by Bemer. A reasonably good agreement is observed between 28.4 and $14.2 \mathrm{MPa}$ axial stress with a value of $M_{\text {oedo }}=3.34 \mathrm{GPa}$. This study extends the data with two $M_{\text {oedo }}$ values of $8.25\left(\right.$ EST28522 $\left.\mathrm{n}^{\circ} 2\right)$ and 7.64GPa (EST28522 $\left.\mathrm{n}^{\circ} 1\right)$ obtained between 113.4 and $56.7 \mathrm{MPa}$. It also confirms the non linear stress dependency of the oedometric modulus. 


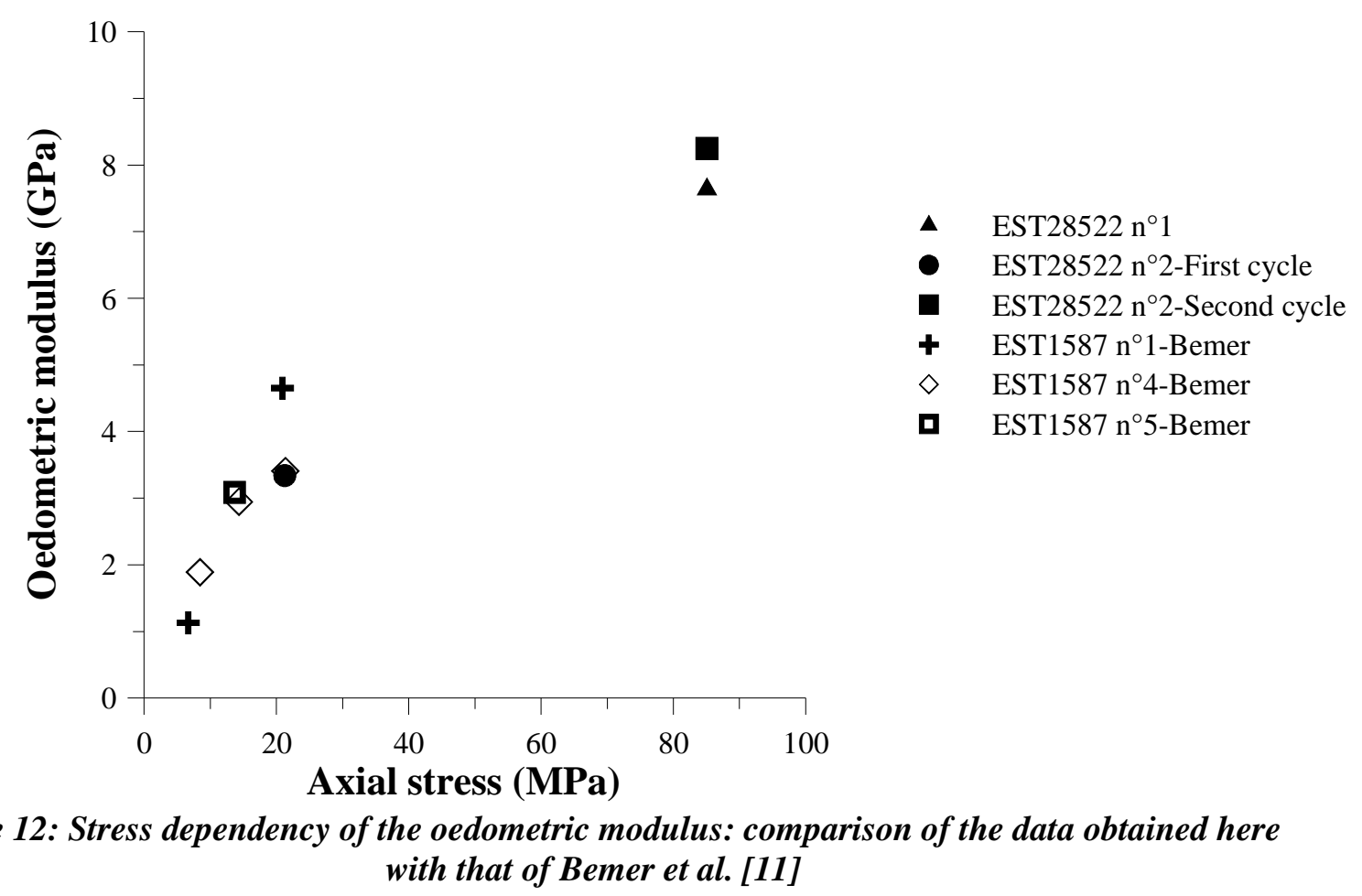

\section{Permeability estimation from oedometric tests}

Oedometric tests are currently used in Soil mechanics to indirectly determine changes in permeability during compression by back analysing the transient response obtained once the sample has been loaded under a constant total stress. Given the difficulty of measuring permeability in low porosity claystones, this method is now examined based on the data obtained here.

The diffusion boundary value problem corresponding to the changes in excess water pore pressure of saturated geomaterials during transient loading or unloading phases has been considered in detail within the Biot poroelastic theory framework by various authors [33-36]. The two transient unloading phases that have been previously used to compute the elastic oedometric moduli are interpreted on the basis of the analytical solution obtained for one dimensional diffusive flow [33]. The first transient phase studied is the unloading phase from 28.35 to $14.17 \mathrm{MPa}$ in test 2 and the second one is the unloading phase from 113.4 to $56.7 \mathrm{MPa}$ in test 1 . The well known general form of the consolidation equation is as follows:

$\frac{d u_{w}}{d t}=c_{v} \frac{\partial^{2} u_{w}}{\partial z^{2}}$

The following expression for the coefficient of consolidation $\left(c_{v}\right)$ was proposed by Coussy [33]:

$c_{v}=\frac{k}{\eta_{w}}\left(\frac{1}{1+b^{2} M C_{\text {oedo }}}\right)$

in which:

$\frac{1}{M}=(b-\phi) C_{s}+\phi C_{w}$ 
$b=1-\frac{C_{s}}{C_{d}}$

$C_{d}$ is the drained isotropic compressibility of the sample, $C_{s}$ is the compressibility of the solid grains $\left(0.02 \mathrm{GPa}^{-1}\right.$ [37]), $C_{w}$ is the water compressibility $\left(0.447 \mathrm{GPa}^{-1} ;[38]\right), \phi$ is the sample porosity at the beginning of each transient phase $(\phi=18.7 \%$ in the first unloading phase of test 2 from 28.35 to $14.17 \mathrm{MPa}$ and $\phi=13.7 \%$ in the second unloading phase of test 1 from 113.4 to $56.7 \mathrm{MPa}$ ).

One can observe in Eq. 6 that the equivalent isotropic compressibility $C_{d}$ is needed to compute the Biot coefficient. To relate $C_{d}$ to the oedometric compressibility $\left(C_{\text {oedo }}=1 / M_{\text {oedo }}\right)$, the stress-strain elastic relationship is written for both isotropic loading and oedometric conditions for a transverse isotropic material [39]:

$$
\left(\begin{array}{l}
\varepsilon_{1} \\
\varepsilon_{2} \\
\varepsilon_{3}
\end{array}\right)=\left(\begin{array}{ccc}
\frac{1}{E_{1}} & \frac{-v_{12}}{E_{1}} & \frac{-v_{12}}{E_{1}} \\
\frac{-v_{21}}{E_{2}} & \frac{1}{E_{2}} & \frac{-v_{23}}{E_{2}} \\
\frac{-v_{21}}{E_{2}} & \frac{-v_{23}}{E_{2}} & \frac{1}{E_{2}}
\end{array}\right)\left(\begin{array}{l}
\sigma_{1} \\
\sigma_{2} \\
\sigma_{3}
\end{array}\right)
$$

where $E_{2}, v_{23}$ are the Young modulus and Poisson ratio in the isotropic plane $\left(x_{2}, x_{3}\right)$ (the bedding plane) and $E_{1}, v_{12}$ are the Young modulus and Poisson ratio in the $\left(x_{1}, x_{2}\right)$ plane (perpendicular to bedding plane), respectively. The following relationship holds:

$$
\frac{v_{12}}{E_{1}}=\frac{v_{21}}{E_{2}}
$$

Under oedometric conditions $\left(\varepsilon_{r a d}=\varepsilon_{2}=\varepsilon_{3}=0, \sigma_{r a d}=\sigma_{2}=\sigma_{3}, \varepsilon_{1}=\varepsilon_{a x}\right.$ and $\left.\sigma_{1}=\sigma_{a x}\right)$, the strainstress relationship becomes:

$$
\begin{aligned}
& \varepsilon_{1}=\frac{1}{E_{1}}\left[1-2 \frac{v_{12} v_{21}}{1-v_{23}}\right] \sigma_{1} \\
& C_{\text {oedo }}=\frac{1}{E_{1}}\left[1-2 \frac{v_{12} v_{21}}{1-v_{23}}\right]
\end{aligned}
$$

Under isotropic loading $\left(\sigma_{1}=\sigma_{2}=\sigma_{3}=\sigma\right)$

$$
\begin{aligned}
& \varepsilon_{v}=\varepsilon_{1}+\varepsilon_{2}+\varepsilon_{3}=\left[\frac{1}{E_{1}}\left(1-4 v_{12}\right)+\frac{2}{E_{2}}\left(1-v_{23}\right)\right] \sigma \\
& C_{d}=\frac{1}{E_{1}}\left[\left(1-4 v_{12}\right)+2 \frac{v_{12}}{v_{21}}\left(1-v_{23}\right)\right]
\end{aligned}
$$

Comparing Eq.7 and Eq.9, the relationship between $\mathrm{C}_{\text {oedo }}$ and $\mathrm{C}_{d}$ is written as:

$$
C_{d}=C_{\text {oedo }} \frac{\left[\left(1-4 v_{12}\right)+2 \frac{v_{12}}{v_{21}}\left(1-v_{23}\right)\right]\left(1-v_{23}\right)}{\left(1-v_{23}\right)-2 v_{12} v_{21}}
$$


According to [12], the Poisson coefficients of the COx argillite are:

$v_{12}=0.35, v_{21}=0.37, v_{23}=0.29$.

Giving, for the COx argillite:

$$
C_{d}=1.5 C_{\text {oedo }}
$$

According to these relations, the estimated values of the equivalent drained isotropic compressibility $\left(C_{d}\right)$ and of the Biot coefficient $(b)$ are hence respectively equal to $0.45 \mathrm{GPa}^{-1}$ and 0.96 for the unloading phase from 28.35 to $14.17 \mathrm{MPa}$ (test 2) and $0.195 \mathrm{GPa}^{-1}$ and 0.96 for the unloading phase from 113.4 to $56.7 \mathrm{MPa}$ (test 1 ).

To solve the diffusion equation (Eq.3), the boundary and initial conditions must be prescribed. In one dimension compression, the sample is drained from top and bottom with a drainage length $\left(H_{d r}\right)$ equal to half of the sample thickness $(5 \mathrm{~mm})$ giving $u_{w}=0$ at $z=0$ and $2 H_{d r}$ at any time. At $t=0$, the instantaneous response in pore pressure $\left(u_{w 0}\right)$ is undrained and defined by the relation:

$$
u_{w 0}=B \Delta p
$$

where $B$ is the Skempton coefficient [40] and $(\Delta p)$ is the mean stress increment. In oedometric conditions, this relation becomes:

$$
u_{w 0}=B\left(\Delta \sigma_{a x}+2 \Delta \sigma_{r a d}\right) / 3
$$

$\sigma_{\text {rad }}$ is calculated from the elastic relationships (Eq.7) assuming $\varepsilon_{r a d}=0$;

The Skempton coefficient is defined as:

$$
B=\frac{C_{d}-C_{s}}{C_{d}-C_{s}+\phi\left(C_{w}-C_{s}\right)}
$$

The Skempton coefficient $B$ is equal to 0.84 for the unloading phase from 28.35 to 14.17 $\mathrm{MPa}$ (test 2) and equal to 0.75 for the unloading phase from 113.4 to $56.7 \mathrm{MPa}$ (test 1).

The analytical solution of the consolidation equation that provides the pore pressure as a function of time $(t)$ and altitude $(z)$ is as follows [41]:

$$
u_{w}(z, t)=\sum_{i=0}^{i=\infty}\left[\frac{2 u_{w 0}}{m} \sin \left(\frac{m z}{H_{d r}}\right)\right] e^{-m^{2} T_{v}}
$$

in which $i$ is an integer and $m=\frac{\pi}{2}(2 i+1)$ and $T_{v}=\frac{c_{v} t}{H_{d r}^{2}}$ is the time factor.

Knowing the pore pressure changes, the changes in strain can be computed. To do so the sample is subdivided into different elementary layers with thickness $d z$ at the altitude $z$. The displacement of this layer at time $t\left(\operatorname{dis}_{\text {elem(z) }}^{t}\right)$ is estimated from the constitutive equation as follows:

$$
\operatorname{dis}_{\text {elem(z) }}^{t}=-b C_{\text {oedo }}\left(u_{w}(z, t)-u_{w 0}\right) \cdot d z
$$

The total displacement of the sample at time $t$ is the integral of $d i s^{t}{ }_{\operatorname{elem(z)}}$ from the bottom to the top of the sample: 


$$
d i s_{\text {total }}^{t}=-b C_{\text {oedo }} \int_{z=0}^{z=2 H_{d r}}\left(u_{w}(z, t)-u_{w 0}\right) d z=2 H_{d r} b C_{\text {oedo }} u_{w 0}-b C_{\text {oedo }} \int_{z=0}^{z=2 H_{d r}} u_{w}(z, t) d z
$$

Assuming homogeneous deformation inside the sample,

$$
\varepsilon_{a x}^{t}=b C_{o e d o} u_{w 0}\left(1-\frac{1}{2 H_{d r}} \frac{\int_{z=0}^{z=2 H_{d r}} u_{w}(z, t) d z}{u_{w 0}}\right)
$$

where $\left(2 H_{d r}\right)$ is the sample height.

Using the expression of $u_{w}$ (eq. 18), we get:

$$
\varepsilon_{a x}^{t}=b C_{o e d o} u_{w 0}\left(1-\sum_{m=0}^{m=\infty} \frac{2}{m^{2}} e^{-m^{2} T_{v}}\right)
$$

The observed strain/time data from the unloading sequences have been fitted with the analytical solution by adjusting the permeability value.

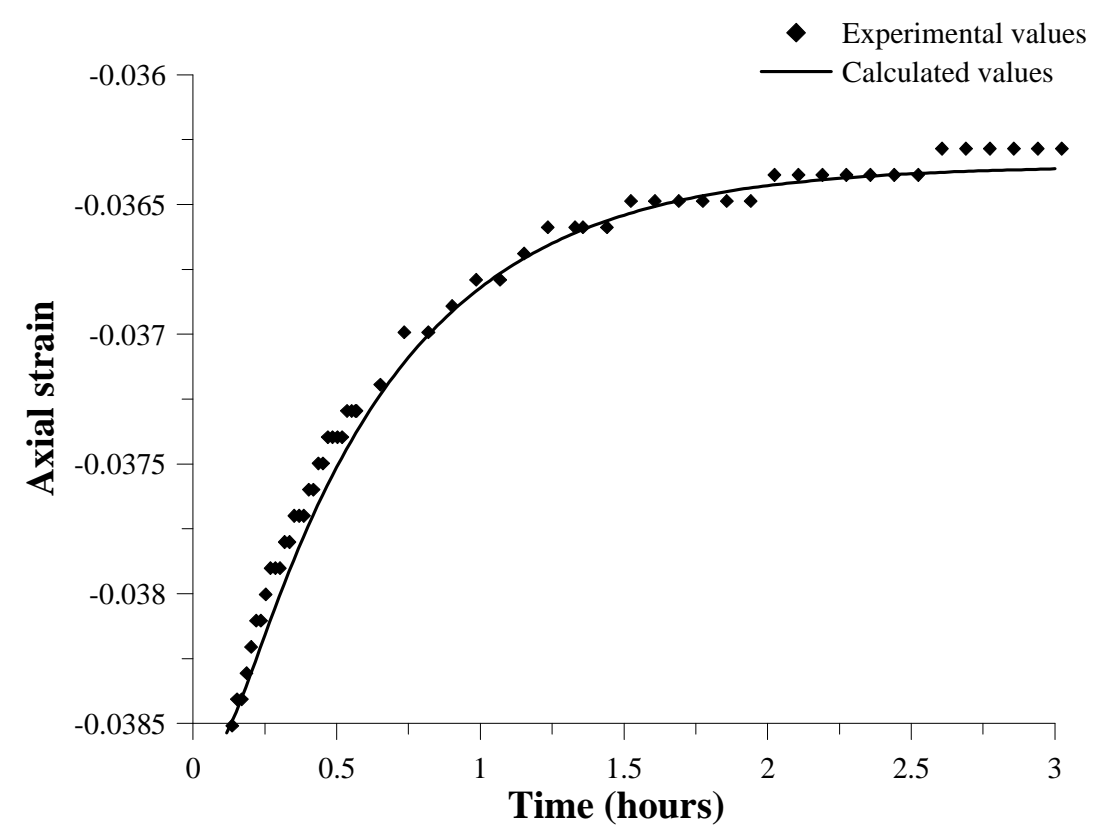

Figure 13: Experimental (EST28522 $n^{\circ}$ 2) and calculated strain changes with time during generated pore pressure diffusion, vertical load equal to 14.17MPa.

The fitting presented in Figure 13 and Figure 14 have been obtained with permeability values of $2 \times 10^{-21} \mathrm{~m}^{2}$ and $0.6 \times 10^{-21} \mathrm{~m}^{2}$ under loads of 14.17 and $56.7 \mathrm{MPa}$, respectively. These values are reasonable for highly compressed COx argillite [42]. 


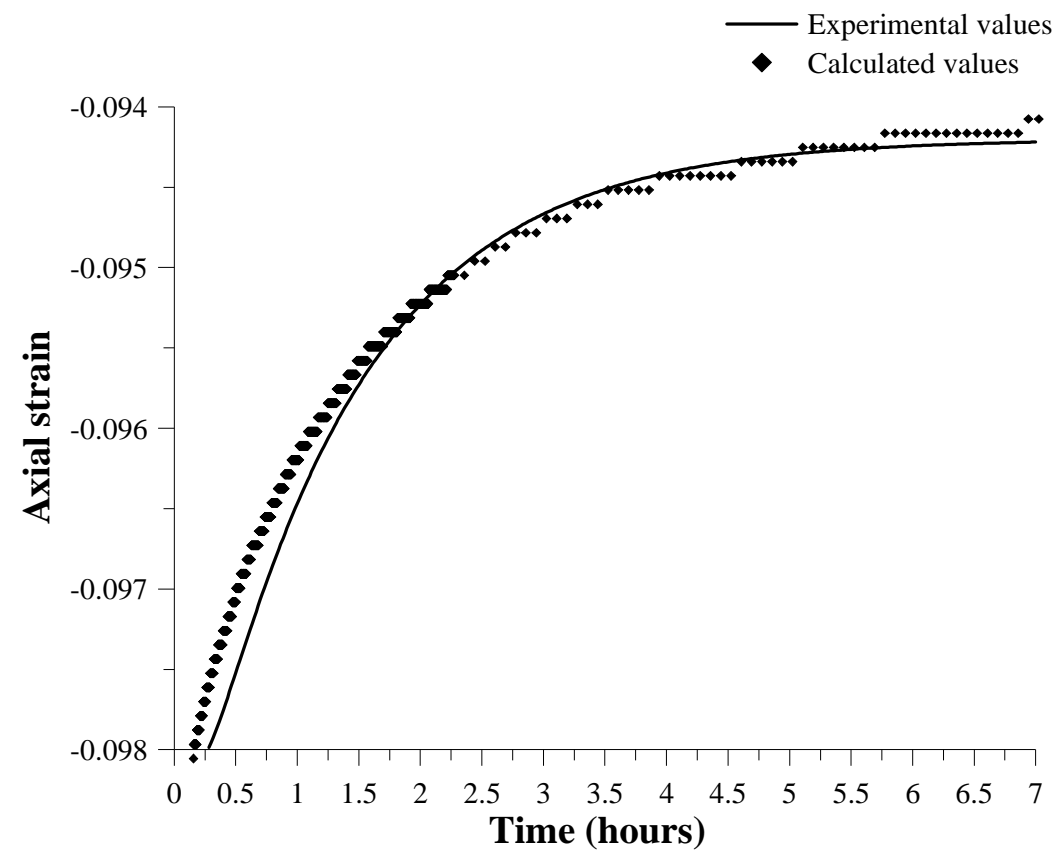

Figure 14: Experimental (EST28522 $n^{\circ} 1$ ) and calculated strain changes with time during generated pore pressure diffusion, vertical load equal to $56.7 \mathrm{MPa}$.

In Figure 15 one can observe that the permeability of the sample decreases at higher applied stress. The sample at higher applied stress has also the smaller porosity.

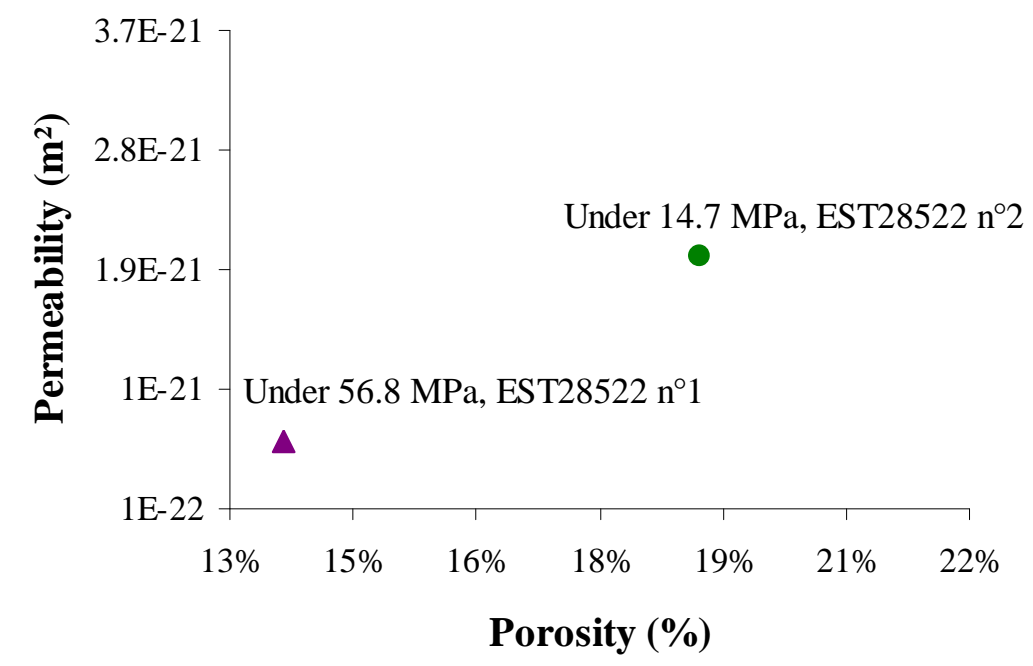

Figure 15: Estimated permeability of COx argillite versus porosity.

\section{Conclusion}

Clay shales often exhibit swelling properties, an interesting property regarding the long term safety of radioactive waste disposal. In the literature, swelling behaviour in rocks has often been linked with the development of cracks and damage, either of a natural or of a manmade origin. An experimental investigation of the compression and swelling behaviour of the Callovo-Oxfordian argillite was conducted to further investigate these aspects. To do so, two series of oedometric tests were carried out. In the first series, the argillite appeared to exhibit a swelling behaviour even when soaked under stresses higher than the in-situ stress. In the second series of tests, the swelling capacity appeared to increase with compression. In both 
cases, swelling was related either to pre-existing cracks due to sample coring, storage, drying, wetting and trimming or to cracks induced during compression. In this regard, compression was suspected to occur by local pore collapse that created micro-cracks that afterwards swelled when hydrated. Indeed, sample compressed at higher stress exhibited higher swelling potential.

Oedometer tests also provided some information on the compression behaviour of the argillite, showing that the determination of a yield stress in a graph giving the volumetric changes with respect to the logarithm of the stress was not as straightforward as in clays. As a consequence, the similarity somewhat considered between argillites and overconsolidated clays is not confirmed. Finally, the transient unloading sequences of the oedometer tests were used to estimate the argillite hydraulic conductivity. This parameter which is essential to assess the long-term safety of radioactive wastes, is difficult to measure and this simple approach provides new useful data.

\section{Acknowledgements}

The work presented in this paper has been carried out during the preparation of the $\mathrm{PhD}$ thesis of the first author that was partly funded by ANDRA, the French Agency in charge the management of radio-active waste disposal. The PhD thesis was co-funded by ENPC, Paris. The views presented here are those of the authors and do not engage ANDRA in any matter.

\section{References}

[1] Wileveau Y, Cornet F.H, Desroches J, Blümling P. Complete in situ stress determination in an. argillite sedimentary formation. Physics and Chemistry of the Earth, Parts. A/B/C, 2007; 32 (8-14), pp 866-878.

[2] Fouche O, Wright H, Cléac'h J.M, Pellenard P. Fabric control on strain and rupture of heterogeneous shale samples by using a non-conventional mechanical test, Applied Clay Science 2004; 26, pp 367-387.

[3] Escoffier S. Caractérisation expérimentale du comportement hydromécanique des argilites de Meuse/Haute-Marne. PhD Thesis, INPL, 2002.

[4] Ozanam O, Hoteit N, Bemer E, Heitz J.F. Experimental determination of poroelastic parameters of a clayey rock. Second Biot Conference on Poromechanics, Grenoble, France, 2002, Zwets \& Zeitlinger, pp 275-280.

[5] Zhang C, Rothfuchs T. Experimental study of the hydro-mechanical behaviour of the Callovo-Oxfodian argillite. Applied Clay Science, 2004; 26, pp 325-336.

[6] Davy C. A, Skoczylas F, Barnichon J.D, Lebon P. Permeability of macro-cracked argillite under confinement: Gas and water testing. Physics and Chemistry of the Earth, 2007; 32 (814), pp 667-680.

[7] Zhang C, Rothfuchs T. Damage and sealing of clay rocks detected by measurements of gas permeability. Physics and Chemistry of the Earth, Parts A/B/C, 2008; 33, Supplement1, pp S363-S373.

[8] Carter T.G, Castro S.O, Carvalho J.L, Hattersley D, Wood K, Barone F.S, Yuen D, Giraldo C.M.K. Tunnelling Issues with Chilean tertiary volcaniclastic rocks . Mir conference; Problemi di stabilità nelle opere geotecniche. Capitolo 11, Torino 2010 . 
[9] Aversa S, Evangelista A, Leroueil S, Picarelli L. Some aspects of the mechanical behaviour of structured soils and soft rocks. Geotechnical Engineering of Hard soils- Soft Rocks, Anagnostopoulos et al. (eds), 1993, Balkema, Rotterdam, ISBN 9054103442.

[10] Vincké O, Boutéca M, Longuemarre P. Investigation of the poromechanical behavior of shales in elastic domain, SPE/ISMR 475, 1998, pp 515-520.

[11] Bemer E, Longuemare P, Vincke O. Poroelastic parameters of Meuse/Haute Marne argillites: effect of loading and saturation states. Applied Clay Science 2004; 26, pp 359366.

[12] Homand F, Shao J, Giraud A, Auvray C, Hoxha D. Pétrofabrique et propriétés mécaniques des argilites. Comptes Rendus Geosciences, 2006; 338 (12-13), pp 882-891.

[13] Pham Q.T, Vales F, Malinsky L, Nguyen Linh D, Gharbi H. Effects of desaturationresaturation on mudstone. Physics and Chemistry of the Earth, 2007; 32, pp 646-655.

[14] Abou-Chakra Guéry A,Cormery F, Shao J.F, Kondo D. A micromechanical model of elastoplastic and damage behavior of a cohesive geomaterial. International Journal of Solids and Structures, 2008; 45(5), pp 1406-1429.

[15] Esteban L. Anisotropies magnétique et de porosité des argilites du Callovo-Oxfordien du laboratoire souterrain de l'Andra (Meuse/Haute-Marne, Bassin de Paris). PhD Thesis, University of Toulouse III, 2006.

[16] Robinet J.C. Mineralogie, porosité et diffusion des solutes dans l'argilite du CallovoOxfordien de Bure (Meuse/Haute-Marne, France) de l'échelle centimétrique à micrométrique. PhD Thesis, University of Poitier, France, 2008.

[17] ANDRA. Dossier Argiles, Référentiel du site Meuse/Haute Marne, 2005.

[18] Montes H.G, Duplay J, Martinez L, Escoffier S, Rousset D. Structural modifications of Callovo-Oxfordian argillite under hydration/dehydration conditions. Applied Clay Science, 2004; 25 (3-4), pp 187-194.

[19] Bornert M, Vales F, Gharbi H, Nguyen Minh D. Multiscale full-field strain measurements for micromechanical investigations of the hydromechanical behaviour of clayey rocks, Strain, 2010; 46 (1), pp 33-46.

[20] Valès F. Modes de déformation et d'endommagement de roches argileuses profondes sous sollicitations hydro-mécaniques. PhD Thesis, Ecole Polytechnique, 2008.

[21] Leong E.C, Tripathy S, Rahardjo H. Total suction measurement of unsaturated soils with a device using the chilled-mirror dew-point technique, Géotechnique, 2003; 53 (2), pp $173-182$.

[22] Delage P, Howat M, Cui Y.J. The relationship between suction and swelling properties in a heavily compacted unsaturated clay. Engineering Geology,1998; 50 (1 -2), pp 31-48.

[23] Fredlund D.G. Rahardjo H. Soil mechanics for unsaturated soils, Wiley, 1993.

[24] Romero E. Characterization and thermo-hydro-mechanical behaviour of unsaturated Boom clay; an experimental study. PhD Thesis, Universitat politècnica de Catalunya, Spain, 1999.

[25] Jurin, J. An account of some experiments shown before the Royal Society; with an enquiry into the cause of the ascent and suspension of water in capillary tubes. Philosophical Transactions of the Royal Society, 1719; 30, pp 739-747. 
[26] Marcial D, Delage P, Cui Y.J. On the high stress compression of bentonites. Canadian Geotechnical Journal, 2002; 39, pp 1-9.

[27] Skempton, A.W, Sowa V.A. The behaviour of saturated clays during sampling and testing. Géotechnique, 1963; 13, No. 4, pp 269-290.

[28] Heitz J.F, Hicher P.Y. The mechanical behaviour of argillaceous rocks - Some questions from laboratory experiments. Proc. Int. Symp. Hydromechanical and Thermohydromechanical Behaviour of Deep Argillaceous Rock, 2002; pp 99-108.

[29] Delage P, Le T.T, Tang A.M, Cui Y.J, Li X.L. Suction effects in deep Boom clay block samples. Géotechnique, 2007 ; 57 (1), pp 239-244.

[30] Delage P. A microstructure approach of the sensitivity and compressibility of some Eastern Canada sensitive clays. Géotechnique, 2010; 60 (5), pp 353-368.

[31] Delage P, Lefebvre G. Study of the structure of a sensitive Champlain clay and its evolution during consolidation. Canadian Geotechnical Journal, 1984; 21 (1), pp 21-35.

[32] Cerrolaza M, Delage P. Microstructure and volume change behaviour of soft clays: a boundary elements simulation. International Journal for Analytical and Numerical Methods in Geomechanics, 1997; 21, pp 665-686.

[33] Coussy O. Poromechanics, Wiley, 2004.

[34] Detournay E, Cheng A.-H.-D. Fundamental of poroelasticy, Chapter 5 in Comprehensive Rock Engineering: Principles, Practice and Projects, Vol. II, Analysis and Design Method, ed. C. Fairhurst, Pergamon Press,1993, pp 113-171.

[35] Hart D.J., Wang H.F. A single test method for determination of poroelastic constants and flow parameters in rocks with low hydraulic conductivities, International Journal of Rock Mechanics \& Mining Sciences, 2001; 38, pp 577-583.

[36] Hsieh P.A., Tracy J.V., Neuzil C.E., Bredehoeft J.D., Silliman S.E. A Transient Laboratory Method for Determining the Hydraulic Properties of' Tight Rocks. Int. J. Rock Mech. Min. Sci. \& Geomech. Abstr, 1981 Vol. 18, pp 245 to 252.

[37] McTigue D.F. Thermoelastic response of fluid-saturated porous rock, Journal of Geophysical Research, 1986; 91(B9), pp 9533-9542.

[38] Spang B. Excel Add-In for Properties of Water and Steam in SI-Units http://www.cheresources.com/staff.shtml, 2002.

[39] Cheng A.H.D. Material coefficients of anisotropic poroelasticity. Int J Rock Mech Min 10 Sci 1997; 34(2): pp 199-205.

[40] Skempton A.W. The Pore Pressure Coefficients A and B, Géotechnique, 1954; 4, pp $143-147$.

[41] Carslaw H.S, Jaeger J.C. Conduction of Heats in Solids, Clarendon press, Oxford, 1959.

[42] Escoffier S, Homand F, Giraud A, Hoteit N, Su K. Under stress permeability determination of the Meuse/Haute-Marne mudstone. Engineering Geology, 2005; 81(3), pp $329-340$. 